\title{
Application of Nano Sized Materials for Mitigating the Corrosion in Concrete: A Review
}

\author{
Bhupesh Jain*, Gaurav Sancheti†, Vaibhav Jain \\ Department of Civil Engineering, Manipal University Jaipur, Dehmi Kalan, off Jaipur-Ajmer Expressway, \\ Jaipur, 303007 Rajasthan, India
}

(Received 05 January 2021; revised manuscript received 22 March 2021; published online 09 April 2021)

\begin{abstract}
Concrete is one of the widely used building materials around the world for the infrastructure development. With the time, the infrastructural structures require maintenance as they bear all types of environmental impacts. Corrosion in concrete is one such environment impact. There is different reason of deterioration of concrete structure such as cracking, delamination and spalling can be occur due to corrosion of reinforcement, which is primary reason of decrease in quality of structure. The major causes for reinforcement corrosion include chloride ingress and carbonation in the concrete structures. Due to this, the volume of embedded steel increases and cracks start appearing. Recent studies have shown great influence of fine materials on the corrosion properties when added in concrete. This paper deals with showcasing the effect of various fine mineral additives like silica fume, nano silica, fly ash etc. that can predict the behavior of concrete against corrosion. The blended mixes of these materials were tested for Open Circuit Potential (OCP) and their results are compared. Effect of chemical additive like rust inhibitor is also discussed as the dosage of additive and method of mixing plays an important role to develop corrosion resistant concrete.
\end{abstract}

Keywords: Nanomaterials, Corrosion, Concrete, Mineral admixture, Silica fume, Nano silica.

DOI: 10.21272/jnep.13(2).02006

PACS numbers: $61.46 .+\mathrm{w}, 61.43 . \mathrm{Gt}$

\section{INTRODUCTION}

Concrete is one of the most preferred construction materials in developing country [1-3]. Generally, concrete provide good protection of reinforcement against the corrosion, because concrete pore solution has very high $\mathrm{pH}$ (>13.5). Reinforcement remain inactive under high alkalinity. Also properly compacted and cured concrete have very low permeability which reduces penetration of agent which corrode the reinforcement like carbon dioxide, chloride and moisture. Very low electric conductivity of concrete limits the rate of corrosion by reducing the flow of charges from anodic to cathodic site $[4,5]$. There are two major cause of corrosion of reinforcement (i) carbonation, and (ii) chloride ions, (either present in concrete constituent or ingress through concrete surface) [6]. Once the corrosion of steel started, it shortens the life of structure by cracking and spalling of the cover because volume of reinforced bar increases after corrosion. The corrosion of reinforcement inside concrete start when the chloride exceeds chloride corrosion concentration limit (CCCL). Further increase of chloride content depassivation of steel increases at very fast rate [7]. Many researcher work to reduce chloride ingress by reducing concrete permeability and increase transportation length by increasing size of cover [8-11].

\subsection{Mechanism of Corrosion}

Corrosion process is similar to the flash battery. The surface of the reinforcement behaves as a mixed electrode (anode or cathode) which are electrically connected complex electrolyte (pore solution present in concrete) and hence reinforced corrosion cell is formed as shown in Fig. 1

Anodic reaction is oxidation reaction, which results in loss of material. Following are different anodic reactions which can occur inside concrete:

$$
\begin{gathered}
3 \mathrm{Fe}+4 \mathrm{H}_{2} \mathrm{O} \rightarrow \mathrm{Fe}_{3} \mathrm{O}_{4}+8 \mathrm{H}^{+}+8 e^{-}, \\
\mathrm{Fe}+2 \mathrm{H}_{2} \mathrm{O} \mapsto \mathrm{HFeO}_{2}^{-}+3 \mathrm{H}^{+}+2 e^{-}, \\
\mathrm{Fe} \rightarrow \mathrm{Fe}^{2+}+2 e^{-}, \\
2 \mathrm{Fe}+3 \mathrm{H}_{2} \mathrm{O} \rightarrow \mathrm{Fe}_{2} \mathrm{O}_{3}+6 \mathrm{H}^{+}+6 e^{-} .
\end{gathered}
$$

Cathodic reactions are the reduction reaction. That results in reduction of dissolved oxygen and form hydroxyl ions. Electron from the decomposition of metal reacting with hydrogen ions and form hydrogen gas [12]

$$
\begin{gathered}
2 \mathrm{H}_{2} \mathrm{O}+\mathrm{O}_{2}+4 e^{-} \rightarrow 4 \mathrm{OH}^{-}, \\
2 \mathrm{H}^{+}+2 e^{-} \rightrightarrows \mathrm{H}_{2} .
\end{gathered}
$$

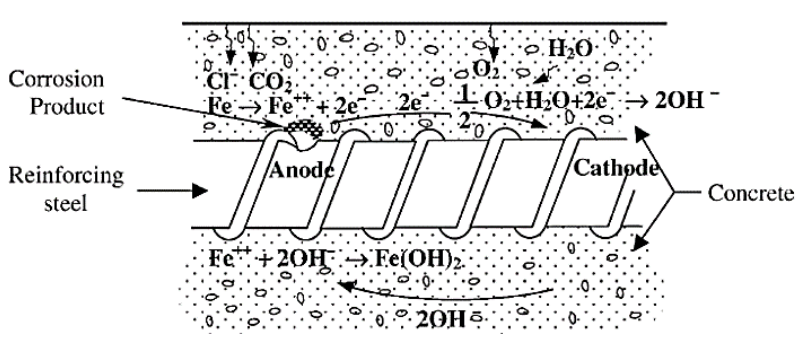

Fig. 1-Schematic illustration of reinforced corrosion cell (electrochemical process) [4]

\footnotetext{
* bhupeshjain1992@gmail.com

$\dagger$ gaurav.sancheti@jaipur.manipal.edu

The results were presented at the International Conference on Multifunctional Nanomaterials (ICMN2020)
} 
Different studies reveal that addition of silica fume, nano silica, fly ash, were increase the resistant against corrosion [13-18]. Silica fume promote hydration of cement and decreasing pore size. sodium molybdate protect steel bars from corrosion by reducing oxygen contact with reinforcement. Sodium nitrite anode rust inhibitor protect steel by forming a passivation film on the surface of steel bar. Reduction in water cement ratio also reduce steel corrosion up to some extent [19-22].

Different form of silica is commonly used in combination with other admixtures to improve the properties of concrete [23]. Combination of Nano silica and silica fume synergistic improve the micro structure of concrete and help to increase the resistance against penetration of water, as well as sulphate, carbonation, and chloride ions [23].

Table 1 - Chemical analysis of fine material

\begin{tabular}{|l|c|c|c|c|c|c|}
\hline $\begin{array}{l}\text { Chemical } \\
\text { analysis }\end{array}$ & $\begin{array}{c}\text { Silica fume } \\
{[\mathbf{2 3}]}\end{array}$ & $\begin{array}{c}\text { Nano silica } \\
{[\mathbf{2 4}]}\end{array}$ & $\begin{array}{c}\text { Cement } \\
{[\mathbf{2 3}]}\end{array}$ & $\begin{array}{c}\text { Granite powder } \\
{[\mathbf{2 5}]}\end{array}$ & $\begin{array}{c}\text { Marble powder } \\
{[\mathbf{2 6}]}\end{array}$ & $\begin{array}{c}\text { Fly ash } \\
{[\mathbf{2 7}]}\end{array}$ \\
\hline $\mathbf{S i O}_{\mathbf{2}}$ & 96.4 & 99.99 & 21.54 & 70.2 & 7.36 & 58 \\
\hline $\mathbf{A l}_{\mathbf{2}} \mathbf{O}_{3}$ & 1.32 & - & 4.95 & 15.8 & 0.46 & 30 \\
\hline $\mathbf{F e}_{2} \mathbf{O}_{3}$ & 0.87 & - & 3.82 & 1.9 & 0.66 & 4.3 \\
\hline $\mathbf{C a O}$ & 0.49 & - & 63.24 & 3.7 & 49.46 & 1.5 \\
\hline $\mathbf{M g O}$ & 0.97 & - & 1.55 & 0.6 & 4.62 & 2.8 \\
\hline $\mathbf{N a}_{2} \mathbf{O}$ & 0.31 & - & 0.48 & 2.1 & - & 3.2 \\
\hline $\mathbf{K}_{\mathbf{2}} \mathbf{O}$ & 1.01 & - & 0.75 & 3.7 & 0.09 & - \\
\hline $\mathbf{S O}_{3}$ & 0.1 & - & 2.43 & 0.6 & 0.41 & - \\
\hline $\mathbf{L o I}$ & - & - & 1.24 & 1.6 & - & - \\
\hline
\end{tabular}

Table 2 - Physical properties of fine materials

\begin{tabular}{|l|c|c|c|c|c|c|}
\hline \multicolumn{1}{|c|}{ Property } & $\begin{array}{c}\text { Silica fume } \\
{[\mathbf{2 3 ]}}\end{array}$ & $\begin{array}{c}\text { Nano silica } \\
{[\mathbf{2 4}]}\end{array}$ & $\begin{array}{c}\text { Cement } \\
{[23]}\end{array}$ & $\begin{array}{c}\text { Granite } \\
\text { powder [25] }\end{array}$ & $\begin{array}{c}\text { Marble } \\
\text { powder [26] }\end{array}$ & $\begin{array}{c}\text { Fly ash } \\
{[27]}\end{array}$ \\
\hline Color & $\begin{array}{c}\text { Gray to off } \\
\text { white }\end{array}$ & White & Gray & Gray to white & White & $\begin{array}{c}\text { Tan to dark } \\
\text { gray }\end{array}$ \\
\hline Particle shape & Globular & - & - & - & - & - \\
\hline Particle size (nm) & 229 & 15 & - & - & - & - \\
\hline Structure & Amorphous & Amorphous & - & - & - & - \\
\hline Bulk density (kg/m ${ }^{3}$ ) & $300-500$ & 1200 & - & - & 880 & 780 \\
\hline Density (g/cm $\mathbf{3})$ & 1.9 & 1.2 & - & - & - & - \\
\hline $\begin{array}{l}\text { Specific surface } \\
\text { area (m/g) }\end{array}$ & $20-25$ & 250 & - & - & 0.6526 & 0.33 \\
\hline Specific gravity & - & - & - & 2.5 & & 2.1 \\
\hline
\end{tabular}

\section{MATERIALS}

\subsection{Silica Fume}

Silica fume is a waste material generated from ferro-silicon industries. To produce silicon metal electric arc furnace is used. Coal, woodchips and quartz are used as raw material. Fume collected from electric furnace is terms as silica fume [28]. One of the most beneficial use of silica fume is to use it as an admixture in concrete.

ASTM C 1240 [29] and AASHTO M 307 [30] is used to specified the quality of silica fume. Chemical composition and physical property of silica fume is shown in Table 1 and Table 2, respectively.

\subsection{Marble Dust}

Marble is commonly used building material for flooring. A large quantity of marble powder is generated by cutting of marble slabs into desired size and shape using diamond wires or a gang saw [32]. Proper disposing of these waste powder is required to protect environment from harmful effect like increasing soil alkalinity which affect the plant life etc. [33]. This solid waste can be used as a filler in concrete. Chemical composition and physical property of marble waste is shown in Table 1 and Table 2.

\subsection{Fly Ash}

Fly ash is a fine powder, from power plants which used coal as a burning fuel. Fly ash mainly consist of siliceous and aluminous material which produce cementious material in presence of lime and water. Hence most widely used application of fly ash is in Portland Pozzolana Cement (PPC). Fly ash are generally classified in two grades namely class $\mathrm{C}$ and class $\mathrm{F}$. If total percentage of silica, alumina and iron is more than 70 then it is class F fly ash [34].

The percentage of fly ash in PPC used in India should be in range of $10-25 \%$ as per IS $1489-1(1991)$ [35]. The quality and other specification of fly ash is specified by ASTM 618 [34] and IS 3812-1 [36]. Fly ash have spherical shape and have ball bearing effect which increases the workability of concrete and reduce the segregation of concrete and make easier to pump.

\subsection{Granite Powder}

Granite is one of the highly used construction material. Around $50 \%$ of the volume of finished final granite 
stone is waste in the form of powder, slurry and small stone pieces. Only $25 \%$ of this waste is used and remaining material is dumped which result in environmental problem such as obstruction of drains, dust related nuisance. Long term deposition of this waste may obstruct percolation of rain water in the ground [37]. Waste granite powder contains high amount of silica about $70 \%$ as shown in Table 1 . Therefore it can be used as pozzolonic material as per ASTM C618 [34].

\subsection{Nano Silica}

Nano silica is white colored high purity amorphous powder of silica. It has approximately $99.99 \%$ silica as shown in Table 1. The mean size of nano silica is $15 \mathrm{~nm}$. Since nano silica has very small size, it has very large specific surface area, good dispersion and very good reactivity [24].

\section{LITERATURE REVIEW}

Ghanei et al. (2020) performed Open circuit potential (OCP) test which tells the chances of steel bar corrosion. If value is more negative than $-276 \mathrm{mV} / \mathrm{SCE}$, it means $>90 \%$ chances of corrosion. OCP value more than - $126 \mathrm{mV} / \mathrm{SCE}$ indicate that less than $10 \%$ chances of corrosion. But uncertainty in corrosion if value lies between $-126 \mathrm{mV} / \mathrm{SCE}$ to $-276 \mathrm{mV} / \mathrm{SCE}[23,25]$. The value of samples with only air entrain admixture without silica fume have more negative than $-276 \mathrm{mV} / \mathrm{SCE}$. It means corrosion probability is more than $90 \%$. After adding silica fume OCE value increases which represent decrease in corrosion probability. The optimum result is obtained at $0.7 \%$ air entraining admixture with $10 \%$ silica fume. The increase in the resistance against corrosion is due to improvement in the pore structure of matrix as a result reduction in the size and number of micro pores present in concrete [23].

Naddaf et al. (2019) used nano silica and silica fume to increase corrosion resistance of concrete. Fixed $11 \%$ replacement of cement, with different combination of silica fume and nano silica is used. Various electrochemical test like impedance spectroscopy, Tafel polarization test, Open Circuit Potential (ASTM C311-05) [40], Linear polarization test is used to find property of concrete before and after adding admixture. The corrosion rate and corroded mass is also found as per ASTM G102-89 [41]. The optimum results obtained at $1.6 \%$ nano silica and $9.4 \%$ silica fume. By replacing $1.6 \%$ nano silica corrosion potential and rate decreases by $12.5 \%$ and $5 \%$ respectively. Improvement in the mix may be due to greater pozzolanic reaction and filling ability of nano silica and dilica fume. Smaller particle size makes very dense concrete which helps to reduce probability of corrosion [42].

Afshar et al. (2020) used pozzolanic materials such as fly ash and silica fume with different coating of inhibitors 2-dimethylaminoethanol to reduce corrosion. Different coating on reinforcement include, galvanized coatings, alkyd coating, zinc-rich primer, polyamide epoxy, polyamide coating, polyurethane coatings, double layer of epoxy and alkyd coating etc. Different test such as Polarization, electrochemical spectroscopy and color adhesion tests were conducted. $3 \%$ FerroGard
901 inhibitors, $10 \%$ silica fume and $25 \%$ fly ash with zinc-rich epoxy primer gave best results. Bode and Bode-phase diagrams is used to compare property of concrete against the corrosion [43].

Ibrahim et al. (2020) studied the effect of adding nano silica in alkali activated concrete (AAC). Several test were performed such as RCPT, chloride migration and half-cell corrosion potentials, corrosion current density and weight loss due to corrosion of embedded rebar. Visual examination of different specimen after test can be observed from Fig. 2. The concrete with OPC have cracking followed by leaching of corrosion product. The corrosion activity in reinforcement embedded in ACC was very less as compared to OPC. Further performance was increased after adding nano silica in ACC. Lower porosity, fewer large pores and lesser connectivity of pores in ACC with silica enhances the performance of concrete. It was found that adding $5 \%$ to $7.5 \%$ nano silica improve the corrosion resistant property and durability of concrete [44].

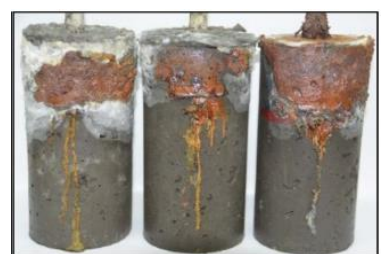

(a) $\mathrm{OPC}$

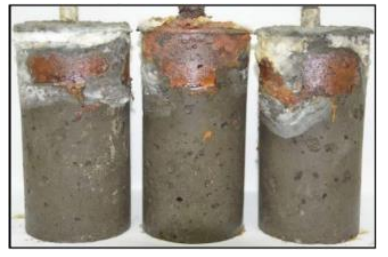

(c) $1 \%$ Nano silica

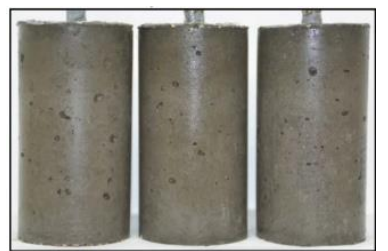

(e) $5 \%$ Nano silica

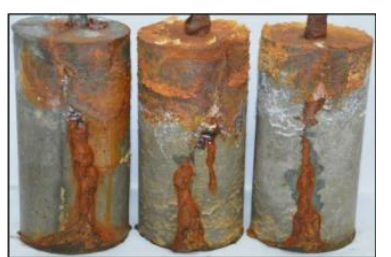

(b) $0 \%$ Nano silica

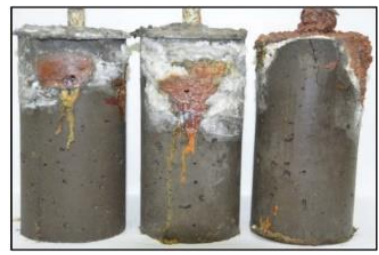

(d) $2.5 \%$ Nano silica

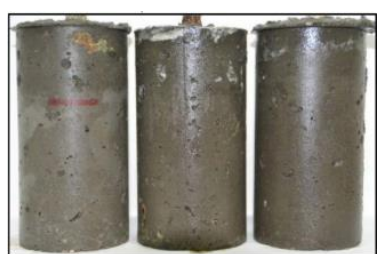

(f) $7.5 \%$ Nano silica
Fig. 2 - Condition of OPC and AAC with different percentage of nano silica [44]

Ghorbani et al. (2020) replace cement with granite and marble waste dust to improve the mechanical and corrosion resistance of concrete. It was observed that at $20 \%$ replacement of cement gave best performance in corrosion resistance as compared to other replacement percentage. Micro- filler action and improved bonding capability of granite and marble powder result in reducing pore diameter, porosity and increase internal surface area of cement matrix. Therefore, permeability of concrete matrix reduces and resistance of concrete against corrosion increases. It is also said that using marble and granite powder increase the surface alkalinity of reinforcement inside concrete which helps in long term corrosion resistance of rebars [25].

Li et al. (2017) found that addition of nano silica and silica fume together have synergistic effects on 
strength and pore reduction. Mini slump, compressive strength and SEM test is used to find concrete property. It is found that $2 \%$ nano silica with $10 \%$ silica fume have good compressive strength and also reduce the demand of superplasticizer. From Fig. 3a, it is observed that fairly large crystal was formed with many large voids. After adding nano silica (refer Fig. 3b) alone some voids are fill but still packing is not very compacted. But after adding both silica fume and nano silica crystal are formed and all voids inside that crystal are properly filled and very dense concrete is formed [38]. Another studied Li et al. observed durability property of concrete. For increasing the compressive strength, sulphate resistance and carbonation resistance adding $1 \%$ nano silica have almost same effect as $10 \%$ Silica fume. But in case of chloride resistance and water resistance $10 \%$ silica fume is more effective. The study reveals that nano silica should not be added alone. It should be added in combination of silica fume for better performance [45].

Wu et al. (2018) studied effect on concrete after adding fly ash and silica fume. Silica fume show good strength in early age as well as later age. But initial fly ash has very less strength but good strength is observed in later age. The RCPT results show that penetration of chloride ion decreases from 1450 to $926{ }^{\circ} \mathrm{C}$ because fly ash has good chloride ions absorption capacity along with improvement in microstructure of concrete by filling pores. The combined effect of fly ash and silica fume reduce sorptivity, chloride permeability and improve hardness in interfacial transition zone. The optimum result was observed when $25 \%$ FA and $5 \%$ SF replaced with cement [27].

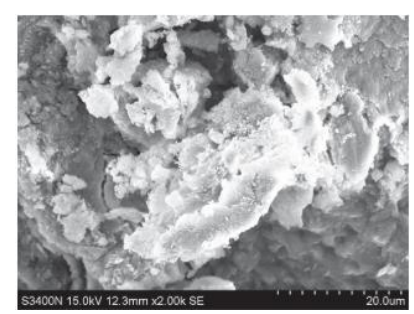

(a)

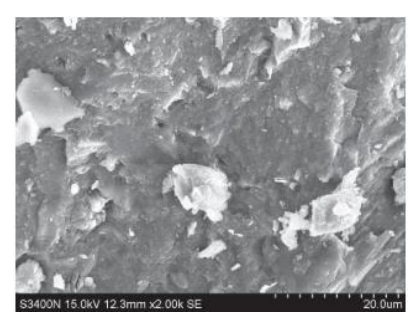

(c)

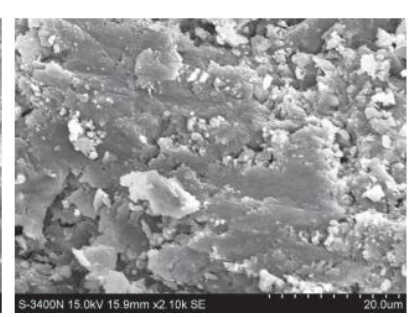

(b)

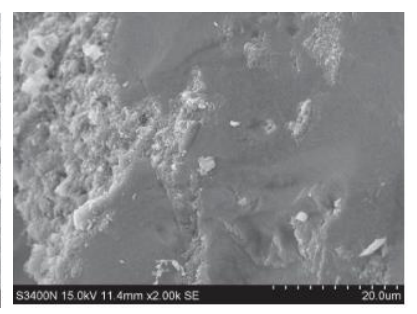

(d)
Fig. 3 - SEM images of concrete with a) $0 \%$ Nano Silica and Silica fume b) $2 \%$ Nano Silica c) $10 \%$ Silica Fume d) $2 \%$ Nano Silica and $10 \%$ Silica Fume [38]

Emamian et al. (2019) study the effect on porosity of concrete after blended cement with nano silica and micro silica. Different models are used for study like Artificial neural network and genetic expression program. In these model water cement ratio, super plasticizer cement ratio, admixture cement ratio, porosity etc. is used as an input parameter. The hyperbolic tangent function is used for both input and output data after normalization. Applied output learning rate and iteration are 0.1 and 1000 , respectively. The microstructure was analyzed by field emission scanning electron microscopy analysis. The combined addition of nano silica and silica fume significantly decrease the porosity and improve mechanical strength. The optimum dosage of replacement found is $2.8 \%$ for nano silica and $9 \%$ for micro-silica [46].

\section{DISCUSSION AND CONCLUSIONS}

The OPC test is most common test which shows the probability of corrosion. More negative OCP value means more probability of corrosion. From Fig. 4, it can be observed that combined effect of nano silica and micro silica have less negative value and hence most effective in resisting corrosion.

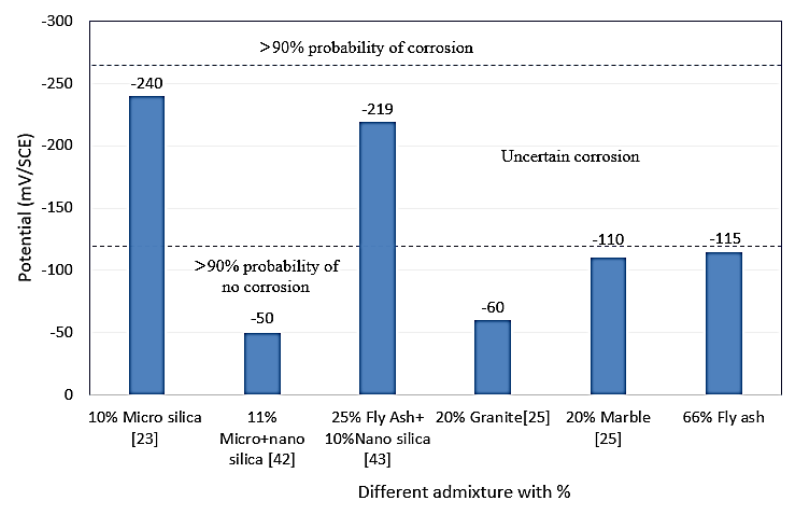

Fig. 4 - OCP value for different admixture

\section{CONCLUSIONS}

- The optimum dosage of adding silica fume and nano silica is $8-10 \%$ and $1-3 \%$, respectively.

- Addition of silica fume and nano silica significantly increase the super plasticizer demand, without super-plasticizer very low workable concrete is achieved.

- Silica fume and nano silica have particle size smaller than cement and hence denser concrete is formed which helps to decrease probability of corrosion.

- Coating of different corrosion inhibitor also help in reducing corrosion.

- The workability of concrete decreases as the waste granite powder increases but adding superplasticizer balance the negative effect of waste granite dust.

- Alkali activated concrete with pozzolanic material also showed good resistance against corrosion.

- Addition of fly ash have multiple advantages such as ability to absorb chloride ions, filling micro pores and increase the hydration product which help to increase resistance of concrete against corrosion.

- The addition of silica with air entraining admixture also improve the resistance against corrosion. 


\section{REFERENCES}

1. N. Singh, S. Varadharajan, A. Jaiswal, S. Verma, Structures 28, 389 (2020).

2. G. Ganesh Prabhu, J.H. Hyun, Y.Y. Kim, Constr. Build. Mater. 70, 514 (2014).

3. R. Siddique, Y. Aggarwal, P. Aggarwal, E.H. Kadri, R. Bennacer, Constr. Build. Mater. 25 No 4, 1916 (2011).

4. S. Ahmad, Cem. Concr. Compos. 25 No 4-5 SPEC, 459 (2003).

5. A. Kenny, A. Katz, Constr. Build. Mater. 244, 118376 (2020).

6. R.G. Pillai, D. Trejo, ACI Mater. J. 102 No 2, 103 (2005).

7. P. Solution, C. Content, P. Layer, N. Sridhar, B. Elsener, U.M. Angst (2008).

8. B.H. Oh, S.Y. Jang, Cem. Concr. Res. 37 No 1, 47 (2007).

9. T. Luping, J. Gulikers, Cem. Concr. Res. 37 No 4, 589 (2007).

10. H.W. Song, C.H. Lee, K.Y. Ann, Cem. Concr. Compos. 30 No 2, 113 (2008).

11. M.H.F. Medeiros, P. Helene, Constr. Build. Mater. 23 No 3, 1476 (2009).

12. R. François, S. Laurens, F. Deby, Corrosion and its Consequences for Reinforced Concrete Structures (ISTE Press - Elsevier: 2018).

13. D. Yoo, Y.S. Jang, B. Chun, S. Kim, Cem. Concr. Compos. 115, 103864 (2021).

14. N. Asrar, A.U. Malik, S. Ahmad, F.S. Mujahid, Constr. Build. Mater. 13 No 4, 213 (1999).

15. E. Gomaa, T. Han, M. Elgawady, J. Huang, A. Kumar, Cem. Concr. Compos. 115, 103863 (2020).

16. Q. Dieu, A. Castel, T. Kim, M.S.H. Khan, Cem. Concr. Res. 139, 106265 (2021).

17. M.R. Sakr, M.T. Bassuoni, Cem. Concr. Compos. 115, 103841 (2021).

18. X. Guo, Y. Wang, P. Huang, S. Shu, Int. J. Fatigue 143, 105977 (2021).

19. H. Wang, et al., Constr. Build. Mater. 262, 120763 (2020).

20. R. Garg, R. Garg, M. Bansal, Y. Aggarwal, Mater. Today Proc. (2020).

21. M.P. Kulakowski, F.M. Pereira, D.C.C.D. Molin, Constr. Build. Mater. 23 No 3, 1189 (2009).

22. M.C. Kang, D.Y. Yoo, R. Gupta, Constr. Build. Mater. 266, 121117 (2021)

23. A. Ghanei, H. Eskandari-Naddaf, T. Ozbakkaloglu, A. Davoodi, Constr. Build. Mater. 262, 120768 (2020).

24. M. Alhawat, A. Ashour, Constr. Build. Mater. 237, 117441 (2020).

25. S. Ghorbani, I. Taji, M. Tavakkolizadeh, A. Davodi, J. de Brito, Constr. Build. Mater. 185, 110 (2018).

26. M. Tennich, A. Kallel, M. Ben Ouezdou, Constr. Build. Mater. 91, 65 (2015).
27. W. Wu, R. Wang, C. Zhu, Q. Meng, Constr. Build. Mater. 185, 69 (2018).

28. What is Silica Fume https://www.silicafume.org/generalsilicafume.html.

29. ASTM C1240-20 Standard Specification for Silica Fume Used in Cementitious Mixtures, ASTM International https://www.astm.org/Standards/C1240.

30. AASHTO M 307-13 (2017) - American Association of State and Highway Transportation Officials (2013).

31. S.K. Das, et al., J. Build. Eng. 32, 101780 (2020).

32. K. Vardhan, R. Siddique, S. Goyal, Constr. Build. Mater. 203, 45 (2019).

33. A. Kanoungo, Natl. Conf. Sustain. Infrastruct. Dev. (2014).

34. ASTM C 618-19 Standard Specification for Coal Fly Ash and Raw or Calcined Natural Pozzolan for Use in Concrete, ASTM International (2019).

35. AASHTO M 295: Standard Specification for Coal Fly Ash and Raw or Calcined Natural Pozzolan for Use in Concrete, American Association of State Highway and Transportation Officials (AASHTO) (2019).

36. IS 3812-1 (2013): Specification for Pulverized Fuel Ash, Part 1: For Use as Pozzolana in Cement, Cement Mortar and Concrete, Bureau of Indian standards (2013).

37. E.A. Shamsabadi, M. Ghalehnovi, J. De Brito, A. Khodabakhshian, Appl. Sci. 2018, 1808 (2018).

38. L.G. Li, Z.H. Huang, J. Zhu, A.K.H. Kwan, H.Y. Chen, Constr. Build. Mater. 140, 229 (2017).

39. L.G. Li, J.Y. Zheng, P.L. Ng, A.K.H. Kwan, J. Build. Eng. 33, 101862 (2021).

40. ASTM C311-05 Standard Test Methods for Sampling and Testing Fly Ash or Natural Pozzolans for Use in PortlandCement Concrete, ASTM International (2005).

41. ASTM G102-89 (2010) Standard Practice for Calculation of Corrosion Rates and Related Information from Electrochemical Measurements, ASTM International (2010).

42. A. Ziaeinia, A. Santana, P. Afonso, A. Zanin, R. Wernke, Procedia Manuf. 22, 399 (2018).

43. A. Afshar, S. Jahandari, H. Rasekh, M. Shariati, A. Afshar, A. Shokrgozar, Constr. Build. Mater. 262, 120034 (2020).

44. M. Ibrahim, M. Kalimur Rahman, M.A. Megat Johari, M. Nasir, E. Adeoluwa Oladapo, Constr. Build. Mater. 262, 120669 (2020).

45. L.G. Li, J. Zhu, Z.H. Huang, A.K.H. Kwan, L.J. Li, Constr. Build. Mater. 157, 337 (2017).

46. S.A. Emamian, H. Eskandari-naddaf, Constr. Build. Mater. 218, 8 (2019).

47. S. Uthaman, R.P. George, V. Vishwakarma, M. Harilal, J. Philip, Constr. Build. Mater. 221, 232 (2019)

\title{
Застосування нанорозмірних матеріалів для зменшення корозії в бетоні: огляд
}

\author{
Bhupesh Jain, Gaurav Sancheti, Vaibhav Jain
}

\section{Department of Civil Engineering, Manipal University Jaipur, Dehmi Kalan, off Jaipur-Ajmer Expressway, Jaipur, 303007 Rajasthan, India}

\begin{abstract}
Бетон є одним з широко використовуваних будівельних матеріалів у всьому світі для розвитку інфраструктури. 3 часом інфраструктурні конструкції вимагають технічного обслуговування, оскільки вони піддаються усім видам впливу навколишнього середовища. Корозія бетону є одним з наслідків такого впливу. Існують різні причини погіршення структури бетону, такі як розтріскування, розшарування та викришування, які можуть відбуватися через корозію арматури, що є основною причиною зниження якості конструкції. Основними причинами корозії арматури є потрапляння хлоридів та карбонізація в бетонних конструкціях. Завдяки цьому об'єм закладеної сталі збільшується і починають з'являтися трішини. Недавні дослідження показали великий вплив дрібних матеріалів на корозійн властивості при їх додаванні в бетон. У роботі розглядається вплив різних дрібнодисперсних мінеральних добавок, таких як кремнезем, нанокремній, зольний пил тощо, які дозволяють передбачити по-
\end{abstract}


ведінку бетону під час корозії. Змішані суміші цих матеріалів тестували за допомогою методу напруги холостого ходу та порівнювали отримані результати. Вплив хімічної добавки, такої як інгібітор іржі, також обговорюеться, оскільки дозування добавки та спосіб змішування відіграють важливу роль у розробці корозійно-стійкого бетону.

Ключові слова: Наноматеріали, Корозія, Бетон, Мінеральні домішки, Кремнезем, Нанокремній. 